\title{
Tuberculous pericarditis in South-west London: an increasing problem
}

\author{
I P WILLIAMS AND M R HETZEL
}

From the Department of Thoracic Medicine, St James' Hospital, London SW12, UK

Tuberculous pericarditis may become more common in South-west London, particularly in Asian patients. We discuss some recent cases.

\section{Patients, methods, and results}

Notifications for tuberculosis by this unit were reviewed from 1974 to 1977 inclusive. There were 160 Asian, 76 British, and six African cases. Glandular involvement was seen in $64 \%$ of the Asians, $11 \%$ of British patients, and none of the Africans.

Eight patients were diagnosed as having tuberculous pericarditis. Six were Asians, who had spent five years or less in Britain, one was African, and the other Irish. Diagnostic criteria were a pericardial effusion, proved by echocardiogram or pericardial aspiration, or both, together with positive bacteriology or histology, compatible with tuberculosis (five patients) or a strongly positive Mantoux test result with negative viral studies (three). Seven patients also had other tuberculous pathology (lymphadenopathy, pleural effusion, or pulmonary infiltration). Patients were reviewed at a mean follow-up period of 16 months (range 6-40).

Two patients responded to chemotherapy (rifampicin, isoniazid, and ethambutol) alone. Four were also given corticosteroids $(30 \mathrm{mg}$ of prednisone a day) from the onset of chemotherapy. All six patients responded to treatment. The other two patients were given corticosteroids only after four and seven weeks of chemotherapy because of increasing pericardial effusions. They did not respond to this delayed treatment with corticosteroids, rapidly developed pericardial constriction, and required surgery. Further details are given in the table.

\section{Discussion}

Though rare, tuberculous pericarditis is particularly prevalent in American negroes (Hageman et $a l, 1964)$ and black South Africans (Schepers, 1962). A survey in Birmingham (Gooi and Morrison Smith, 1978) showed 41 cases, of whom 33 were Asians. The authors attributed this to the high incidence of tuberculosis among Asians in their area. In this unit the annual rate of notifications for tuberculosis has doubled between 1974 and 1977. While this increase is mainly due to Ugandan Asian immigrants, our results nevertheless suggest that the incidence of tuberculous pericarditis is higher than might have been expected from the overall racial distribution of notifications. We can find no data on the incidence of tuberculous

Table Details of eight cases of tuberculous pericarditis

\begin{tabular}{|c|c|c|c|c|c|c|c|}
\hline Age & $\operatorname{Sex}$ & Country of origin & $\begin{array}{l}\text { Duration of symptoms } \\
\text { (months) }\end{array}$ & $\begin{array}{l}\text { Positive tuberculous } \\
\text { pathology }\end{array}$ & Pericardial tap & $\begin{array}{l}\text { Other tuberculous } \\
\text { features }\end{array}$ & $\begin{array}{l}\text { Treatment } \\
\text { and outcome }\end{array}$ \\
\hline 26 & $\mathbf{M}$ & Pakistan & 1 & & & Mediastinal glands & C \\
\hline 64 & $\mathbf{F}$ & $\begin{array}{l}\text { India } \\
\text { (via E Africa) }\end{array}$ & 4 & Sputum culture & & Pleural effusion & $\mathbf{C}$ \\
\hline 38 & $\mathbf{M}$ & $\begin{array}{l}\text { India } \\
\text { (via E Africa) }\end{array}$ & 3 & & Bloodstained & & $\mathbf{P}$ \\
\hline 26 & $\mathbf{M}$ & $\begin{array}{l}\text { India } \\
\text { (via E Africa) }\end{array}$ & 1 & $\begin{array}{l}\text { Pericardial } \\
\text { Fluid culture }\end{array}$ & Bloodstained & Pleural effusion & $\mathbf{P}$ \\
\hline 26 & $\mathbf{F}$ & India & 3 & $\begin{array}{l}\text { Lymph node } \\
\text { culture/histology }\end{array}$ & $70 \%$ Polymorphs & $\begin{array}{l}\text { Pleural effusion } \\
\text { nodes, pulmonary } \\
\text { shadows }\end{array}$ & $\mathbf{P}$ \\
\hline 56 & $\mathbf{M}$ & Ireland & 5 & & Bloodstained & Pulmonary shadows & $\mathbf{P}$ \\
\hline 28 & $\mathbf{M}$ & Zambia & 1 & $\begin{array}{l}\text { Pericardial } \\
\text { histology }\end{array}$ & $90 \%$ Polymorphs & Pleural effusion & $\mathbf{S}$ \\
\hline 23 & $\mathbf{M}$ & $\begin{array}{l}\text { India } \\
\text { (via E Africa) }\end{array}$ & 2 & $\begin{array}{l}\text { Pericardial and } \\
\text { node histology }\end{array}$ & $\begin{array}{l}\text { Failed } \\
\text { (constriction) }\end{array}$ & $\begin{array}{l}\text { Pleural effusion } \\
\text { Lymph nodes }\end{array}$ & $\mathbf{S}$ \\
\hline
\end{tabular}

$\mathrm{C}=$ Responded to chemotherapy alone; $\mathbf{P}=$ Responded to chemotherapy plus corticosteroids; $\mathbf{S}=$ No response to chemotherapy, late use of corticosteroids ineffective, subsequent pericardectomy necessary. 
pericarditis in Asia but suggest that Asians are predisposed to this complication. Tuberculous pericarditis may follow involvement of mediastinal nodes, and it is interesting that both Asians ( $\mathrm{Re}$ search Committee, BTTA, 1973) and negroes (Schepers, 1962) have a high incidence of glandular involvement.

Pericarditis is a serious complication of tuberculosis, with an untreated mortality rate of 80 $90 \%$ in the acute stage (Hageman et al, 1964) and almost inevitable subsequent pericardial constriction. Early chemotherapy improves survival and appears to reduce the likelihood of late pericardial constriction. The value of corticosteroids is debatable in this condition. While they may suppress the acute inflammatory reaction (Rooney et al, 1970), their ability to prevent subsequent pericardial constriction is less certain. Gooi and Morrison Smith (1978) found that the use of corticosteroids during the acute illness produced a more rapid clinical improvement, but they could not prove that the risk of subsequent constriction was reduced. We found no way of predicting which patients were at risk of pericardial constriction; thus two patients responded to chemotherapy alone yet two others eventually needed surgery despite the introduction of corticosteroids. With this reservation, however, our results suggest that immediate treatment with corticosteroids is important since four of our patients who were thus treated developed no complications, while the late introduction of corticosteroids was of no apparent value to the two patients who subsequently needed pericardectomy.

\section{References}

Gooi, H C, and Morrison Smith, J (1978). Tuberculous pericarditis in Birmingham. Thorax, 33, 94-96.

Hageman, J H, D'Esposo, N D, and Glenn, W W L (1964). Tuberculosis of the pericardium. A longterm analysis of 44 proved cases. New England Journal of Medicine, 270, 327-332.

Research Committee, British Thoracic and Tuberculosis Association (1973). A tuberculosis study in England and Wales 1971; the influence of immigration and country of birth upon notifications. Tubercle, 54, 249-260.

Rooney, J J, Crocco, J A, and Lyons, H A (1970). Tuberculous pericarditis. Annals of Internal Medicine, 72, 73-81.

Schepers, G W H (1962). Tuberculous pericarditis. American Journal of Cardiology, 9, 248-276.

Requests for reprints to: Dr I P Williams, Department of Thoracic Medicine, St James' Hospital, London SW12. 